DEPÓSITO LEGAL ZU2020000153

Esta publicación científica en formato digital

es continuidad de la revista impresa

ISSN 0041-8811

E-ISSN 2665-0428

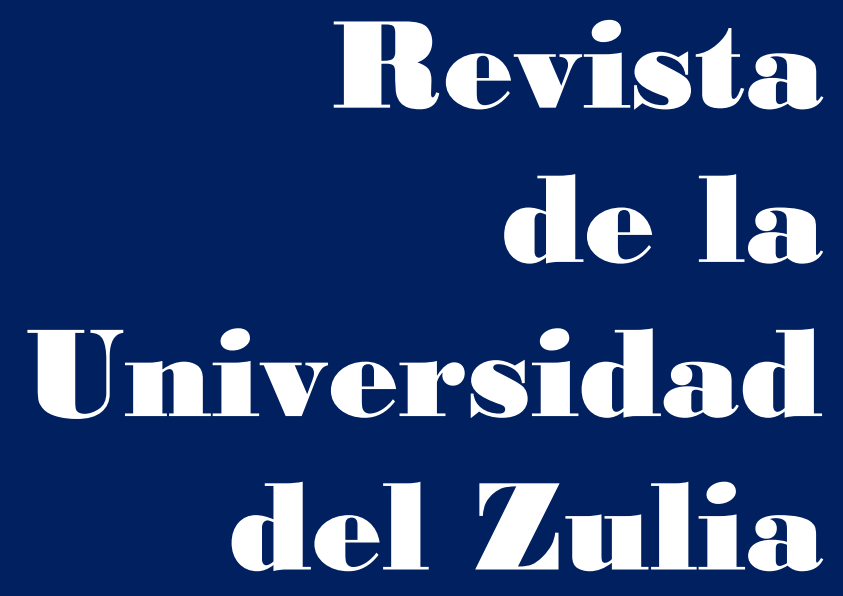

Fundada en 1947

por el Dr. Jesús Emrique Lossada

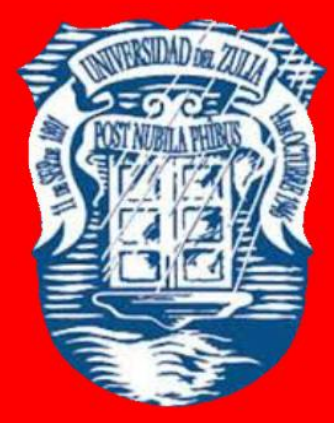

Ciencias

Sociales

y Arte

Año $12 \quad N^{\circ} 34$

Septiembre - Diciembre 2021

Tercera Época

Maracaibo-Veneruela 


\title{
Clasterization tendences of Ukraine's tourism sphere and way out of the COVID-19 pandemic crisis
}

\author{
Nina Rybalchenko* \\ Stanislav Bilohur** \\ Roman Oleksenko*** \\ Valentyna Voronkova**** \\ Iryna Verkhovod*****
}

\begin{abstract}
The article considers the clustering trends in ukraine's tourism sector, aimed at a further rise of the tourism industry, overcoming its negative effects of the COVID-19 pandemic and achieving sustainable development. The need to create tourism clusters and other topics on the organization of tourism with state executive authorities as well as professional tourism associations on attracting investment and providing institutional and consulting assistance to small tourism enterprises is being investigated. The foreign experience was analyzed, as well as the distribution of tourist groups in Ukraine by tourist types in the period 2019-2020. Method: analysis and synthesis, systematization of materials, historical and logical, comparative, systemic and structural, which allowed to study the trends in the tourism industry. Conclusions. The grouping of the sphere of tourism in Ukraine must be developed under the close attention of the government, state and local authorities, public figures, civil society, companies, because it requires not only the containment of the pandemic, but also the development of forms of tourism competitiveness, investment in this industry, the provision of jobs for workers dismissed during the pandemic, the use of the most advanced innovative technologies for the development of creative tourism industries, which will help to get the industry out of the crisis.
\end{abstract}

KEYWORDS: cluster; tourism sector; COVID-19; investment; tourism cluster; tourism potential.

* Dmytro Motornyi Tavria State Agrotechnological University, Melitopol, Ukraine. ORCID: https://orcid.org/0000-0003-3358-2249. E-mail: ninarybka07@mail.com

**Alfred Nobel University, Dnipro, Ukraine. ORCID: https://orcid.org/0000-0001-6755-7231. E-mail: bbilogur@gmail.com

***Dmytro Motornyi Tavria State Agrotechnological University, Melitopol, Ukraine. ORCID: https://orcid.org/0000-0002-2171-514X. E-mail: roman.xdsl@ukr.net

***Zaporizhzhia National University, Ukraine. ORCID: https://orcid.org/0000-0002-0719-1546. Email: valentinavoronkova236@gmail.com

*****Bohdan Khmelnitsky Melitopol State Pedagogical University, Ukraine. ORCID: https://orcid.org/0000-0002-9176-2574. E-mail: verkhovod-ira@ukr.net 


\section{Tendencias de agrupamiento en la esfera turística de Ucrania y salida a la crisis de la pandemia de COVID-19}

RESUMEN

El artículo considera las tendencias de agrupamiento en el sector turístico de Ucrania, dirigidas a un nuevo ascenso de la industria del turismo, superando los efectos negativos de la pandemia del COVID-19 y logrando el desarrollo sostenible. Se investiga la necesidad de crear agrupaciones turísticas y otros temas sobre la organización del turismo con las autoridades ejecutivas estatales, así como las asociaciones profesionales de turismo sobre la atracción de inversiones y la prestación de asistencia institucional y de consultoría a las pequeñas empresas turísticas. Se analizó la experiencia extranjera, así como la distribución de los grupos turísticos en Ucrania por tipos turísticos en el período 2019-2020. Método: análisis y síntesis, sistematización de materiales, histórico y lógico, comparativo, sistémico y estructural, que permitió estudiar las tendencias en la industria del turismo. Conclusiones. La agrupación de la esfera del turismo en Ucrania debe desarrollarse bajo la estrecha atención del gobierno, las autoridades estatales y locales, las figuras públicas, la sociedad civil, las empresas, porque requiere no solo la contención de la pandemia, sino también el desarrollo de formas de competitividad turística, la inversión en esta industria, la provisión de empleos para los trabajadores despedidos durante la pandemia, el uso de las tecnologías innovadoras más avanzadas para el desarrollo de las industrias de turismo creativo, que ayudará a sacar a la industria de la crisis

PALABRAS CLAVE: clúster; sector turístico; COVID-19; inversión; clúster turístico; potencial turístico.

\section{Introduction}

The relevance of the research topic is that the whole society, including Ukraine, is experiencing difficult circumstances pandemic COVID-19, which affected the modern world - society, economy, politics, and led to the decline of the economy in general and the tourism industry, in particular. Therefore, the modern economy has entered a crisis caused by the global consequences, which questioned the globalization itself as such. The tourism sphere has so far multiplied as the most affected by the COVID-19 pandemic, which, in turn, has affected the world economy (Hernández et al, 2021). Therefore, the search for ways out of the tourist sphere from the phase the potential bankruptcy becomes a priority task not only for tourism itself, but also for the governments of many countries. It is no coincidence that the concept of "new normality" as a characteristic of our existence with masks, quarantine, self- 


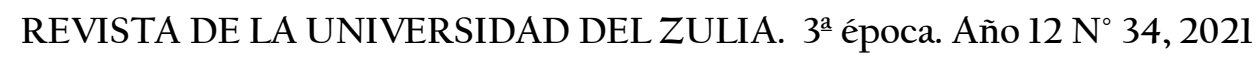

Nina Rybalchenko et al. /// Clasterization tendences of Ukraine's tourism sphere ... 60-75

DOI: http://dx.doi.org/10.46925//rdluz.34.05

isolation, lockdown, social distance, caused by such terms as "2019-nCoV", "SARS-Cov-2", "COVID-19", influencing on the lives of the millions of people has appeared.

-The research object: the conceptual model of clustering tourism sphere of Ukraine as a complex social and economic phenomenon, develops as a dynamic process.

-The subject of the study: trends in the development of tourism industry clustering will contribute to overcoming the COVID-19 pandemic crisis.

\section{Literature review}

For the analysis we use the works of domestic and foreign scientists such as: (Voronkova et al., 2020), the way global data distribution on the development of digital technology, information technology, robotics, which are now so actively burst into the tourist gallery, and download information in analytical information, information technology, information technology specifically search for data about their customers or data clustering. The work "COVID-19: The Great Reset" by K. Schwab and T. Mullery, which is a serious study of the problems of COVID-19, which recognizes at the same level that people have not made the ability to write in such a deep industrial collapse, the manifestation of the "New Post-Covid Normal" (COVID-19: The Great Reset / Forum Publishing) is very relevant for the study. In Cuomo A. "American Crisis: Leadership Lessons on the COVID-19 Example" (Pandemic. New York: Crown Publishing Group, 2020) Galloway S. "Post-Crown: From Crisis to Opportunity" (New York: Portfolio, 2020), Hans J. "Economics in the COVID-19 Era" (Cambridge, Massachusetts, USA. 2020) Presented a rich factual material on the course of the crisis, provided great statistical data COVID -19 to analyze plans to analyze these issues - Economic, social, demographic, environmental, which took part in the people' s lives and created critical pandemic consequences. A number of papers to analyze in the article Ryan A. Born, "Economics in One Virus: An Introduction to Economic Reasoning with COVID-19" (Washington: Cato Institute, 2021), Caro D., "Transforming Nations After COVID. -19 Pandemic/Management, Change, Strategy, and Positive Leadership" (Cham: Springer International Publishing. 2021) Demonstrate the characteristics of the economy in the pandemic period, where so, presented factual material in the pandemic crisis that led to revision. can be compared from the 2008-2009 crisis.

For us this material was very valuable, because in its background we showed the fall and the tourist industry, against which the existence of "new post-covid normality" is formed, 


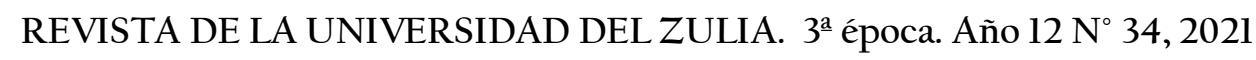

Nina Rybalchenko et al. /// Clasterization tendences of Ukraine's tourism sphere ... 60-75

DOI: http://dx.doi.org/10.46925//rdluz.34.05

in which a person has to adapt and shape his being in the conditions of the economy fall, uncertainty, instability, complexity (VUCA concepts) and to predict his future. We also rely on our own study (Nikitenko, Voronkova, Andriukaitiene, Oleksenko, 2021), in which a metaphysical foundation crisis was discovered, people were forced to live in a total crisis, since the established ways of human existence in this world were lost. We appreciate the legacy of Shcherbakov A. "The impact and consequences of the COVID-19 pandemic: socioeconomic dimensions" (MIR (Modernization. Innovations. Development). 2021), which showed in a systematic way the development of coronavirus pandemic problems and measures to counteract it by national authorities and international organizations, which have already implemented a number of activities.

The works show that the sphere of tourism has suffered the most as a result of the pandemic, and at the same time has a high ability to regenerate. According to the experts of the World Tourism Organization, will recover in the next few months. But with some adjustments: for example, travelers will seek environmentally friendly and more uninhabited areas, respecting the social distance. Ukraine has the necessary tourist potential, a variety of origins and opportunities to use, indicates the search for a way out of the crisis and the formation of new tourist activity concept parameters. Therefore, if it is effectively used, travel and leisure industry can be one of the key steps to overcome the crisis, providing a stable income to state and local budgets, providing jobs and redistribute investment in their favor.

\section{Research methodology}

To determine the tourism clusters components as well as genesis of their mechanisms formation in Ukraine the methods of theorizing and historical formalization were used. To study foreign practices of tourism sphere clusters creation the methods of system analysis, comparison, sampling and description were used. To justify the scientific foundations and approaches to the development of tourist clusters in Ukraine the methods of grouping, modeling and forecasting were used. To determine the tourism cluster's place in the public policy system of medical and therapeutic and recreational areas was determined by the presence of scientific developments in this area. The method of system analysis and synthesis was used, due to which it was possible to bring together into a system disparate data about the COVID-19 pandemic crisis and made a conclusion about the tourism sector clustering trend in Ukraine and the way out of the COVID-19 pandemic crisis. The comparative method 


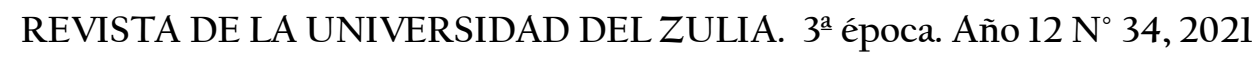

Nina Rybalchenko et al. /// Clasterization tendences of Ukraine's tourism sphere ... 60-75

DOI: http://dx.doi.org/10.46925//rdluz.34.05

or the cross-cultural analysis method allowed to compare the development of the tourism industry in Ukraine and abroad and to show the creation conditions of the tourism cluster multilevel model from the position of its main essence components. The axiological analysis method allowed to reveal the tourism industry values, which are coming down to the identification of its components such as creativity, creativity, exclusive development, wellbeing, safety, adaptation. The method of cybernetic and statistical analysis allowed to construct the distribution of tourist clusters (TC) in Ukraine by tourism types in the period 2019-2020. To distribute tourist clusters on certain functional directions of tourist activity helped methods of structural-functional analysis, and ways out of the COVID-19 pandemic crisis helped modeling and forecasting methods. To form a conceptual model of tourist clustering in Ukraine as a complex social and economic phenomenon, developed as a dynamic process, helped the method of compression analysis and synthesis. The complex of general theoretical and specific methods and approaches which helped to solve the set tasks and to form the cauterization model of tourist sphere of Ukraine and to find the ways out of COVID-19 pandemic crisis was used as a result of the carried out research. Informatiological method aimed at the use of new creative technologies BIG DATA. The research methodology was generally aimed at the fact that the clustering of the Ukraine tourism sphere contributed to the new tourism industry recovery, overcoming its negative consequences and achieving sustainable development.

\section{Results and Discussion}

Since March 11, 2020, HEI has qualified the spread of COVID-19 as a pandemic. In Ukraine today, due to the influence of exogenous and endogenous factors, in particular the spread of viral diseases, COVID-19 is a significant backlog in the implementation of measures to overcome the crisis and support the tourism sector, poses a serious threat to the competitiveness of the industry in the global market during the predicted recovery period during 2021. We have established that the digital economy contributes to technological progress and under the pressure of global trends develops various economic models of scientific and technological and digital progress, which are based on solving man' problems, science, society (Voronkova Valentyna H. et al., 2020).

The development of the tourist sphere requires to use effective organizational and economic instruments of public policy, which in turn provide opportunities for the formation 


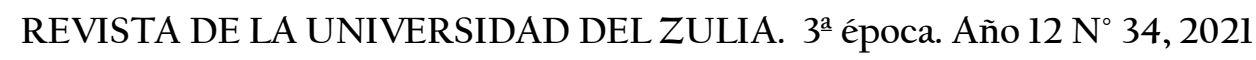

Nina Rybalchenko et al. /// Clasterization tendences of Ukraine's tourism sphere ... 60-75

DOI: http://dx.doi.org/10.46925//rdluz.34.05

of cluster structures in order to strengthen the position in the market of relevant services while increasing economic entity's share in various consumer segments (Ortina, 2015; Khlopyak, 2015).

Abroad, cluster models in tourism are actively implemented in Belgium, Greece, Ireland, Spain, Italy, Norway, Poland, France, Scotland and other countries of the world (Lytvynenko et al, 2020). Their tourist clusters are annually visited by several million tourists; this accounts for almost $1 \%$ of the world's trade turnover in tourism (Kovaleva, Alisheva, 2008; Porter, 1993); Timchishin-Chemeris,2015).

Cluster structures, as a form of commercial implementation in the entrepreneurial environment, have a rather long history of practical use on a global scale - since the 60's-70's. since the first industrial clusters appeared in the automobile industry (Rybalchenko, 2018; Rybalchenko, 2020).

In developed countries at the end of the last century - beginning of the new century, the cluster policy began to be widely used in the conditions of transition to a service economy, which allowed improving the efficiency and quality of many services types. At the same time, there was a certain transformation of organizational and economic approaches to the design and further functioning of such clusters, which was conditioned by the specific features of services as an economic good (Rybalchenko, 2018; Rybalchenko, 2020). In modern conditions of the information society, the "best practices" of innovation clusters were created, concentrated in the United States, the European Union, and Southeast Asia. According to experts, clustering covers about $50 \%$ of the economies of the world's leading countries. As an example of new forms of tourism industry development are innovative clusters: Silicon Valley, French competitiveness clusters, clusters in Finland, the international cluster Eindhoven-Löwen-Ahen (ELAt), Biotechnology Valley, shipbuilding cluster in South Korea, mechanical engineering clusters in Japan, the "Shanghai zone" of the People's Republic of China.

Taking into consideration the importance for the socio-economic development of regions and territories, tourist clusters began to appear among the first in the foreign service economy, which were aimed at expanding the opportunities and capacity of the tourist market due to the optimization of relevant organizations located in close geographical proximity and capable of forming and implementing a unified tourist product (Perminova,1999). 


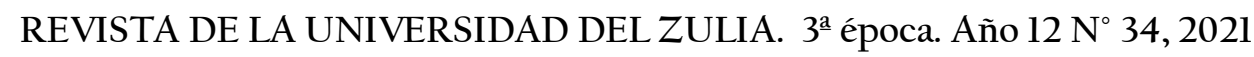

Nina Rybalchenko et al. /// Clasterization tendences of Ukraine's tourism sphere ... 60-75

DOI: http://dx.doi.org/10.46925//rdluz.34.05

In the mid-2000s the practice of creating tourist clusters began to spread in Ukraine. Having analyzed the regulatory framework in the tourism sector, we can argue that the creation and development of tourist clusters should form the basis for the formation of national regulatory documents such as the Strategy for Sustainable Development of Tourism and Resorts in Ukraine for the period up to 2026 (goverment portal), new targeted state programs to develop domestic and inbound tourism in Ukraine, as well as regional programs and strategies of tourist sector development. In the past decade, our country has accumulated considerable experience in the formation of clusters, aimed at the maximum satisfaction of the demands of both domestic consumers and foreign tourists. In Ukraine the clusters are created and function on the basis of such tourist centers:

1) Kamyanets-Podilsky tourist cluster, providing for the development of cognitive tourism, the provision of services for long-term accommodation, catering, health, as well as the organization and holding festivals and fairs;

2) Lviv Tourist Alliance with the Lviv promotion in domestic and international tourism markets, in turn, requires the implementation of activities to improve the competitiveness of domestic tourism services and infrastructure of the said city (Rybalchenko, 2020).

The percentage distribution of tourist clusters in Ukraine by type of tourism in 2019 and 2020 is shown in Fig. 1.

But there are a enough problems with the implementation of the clustering principles in the tourism sphere in Ukraine. In our opinion, they include the following:

1. Insufficient level of utilization of allocated funds, violation of the terms of design, installation and construction works, failure to meet the schedule of commissioning of facilities, negligent attitude to the process of acceptance-transfer of facilities to the regional balance, and the like. Thus, back in 2016, the program for the creation of tourist clusters provided for the opening of 16 clusters, not a single one was fully completed, and from 25 facilities that provide tourist infrastructure, only 11 were put into operation, that is, $44 \%$. As of October 1, 2017, their technical readiness ranged from 30\% to 77\% (Shelemet'va, 2019) 
REVISTA DE LA UNIVERSIDAD DEL ZULIA. 3é época. Año $12 \mathrm{~N}^{\circ}$ 34, 2021

Nina Rybalchenko et al. /// Clasterization tendences of Ukraine's tourism sphere ... 60-75

DOI: http://dx.doi.org/10.46925//rdluz.34.05

Fig. 1. Distribution of tourist clusters (TC) in Ukraine by type of tourism in 2019-2020. Source: compiled from data.

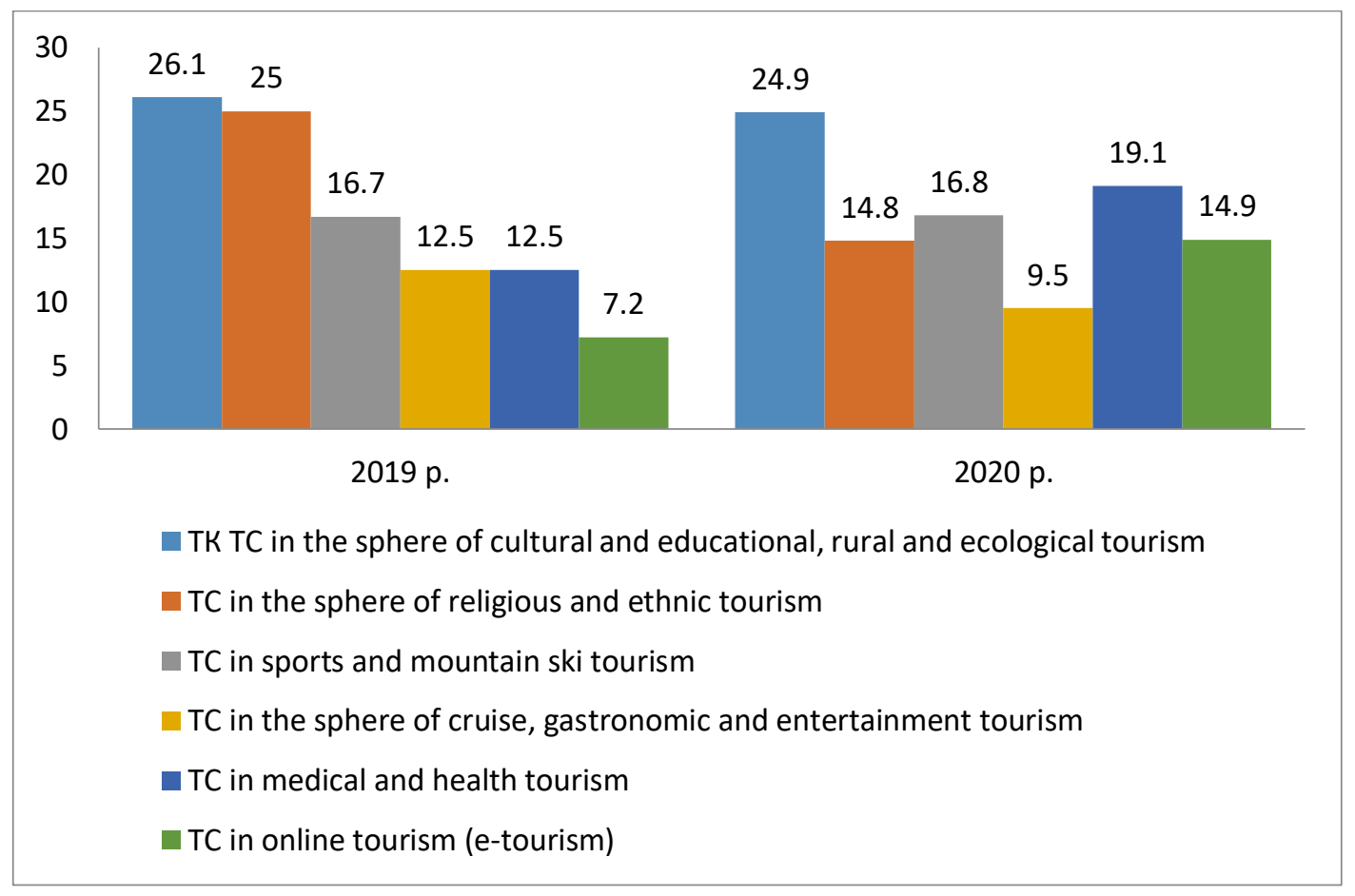

The experience of creation and functioning of tourist clusters abroad shows that the basis of their activity is the provision of services for comfortable accommodation, proper catering and organization of thematic, educational, agrotouristic and other recreational activities and occupations. As you know, in Greece there is an active tourist cluster "Wine, Gastronomy, Tourism", in Northern Scotland - rural (green) tourist cluster, in the Republic of Poland - cluster "Pottery wheel", "Baltic coast", etc. These and other countries have defined their tourist smart specialization, which allows qualitatively differ and win in the national and international tourist markets (Rybalchenko, 2018).

2. the use of corrupt schemes in the allocation and investment of funds, allocated overstatement of the cost of work to create the cluster, non-payment and delays in wages and social security during the preparatory work during the construction or reconstruction phase, and the like. One of the most famous cases is the initiation of criminal cases (Rybalchenko, 2018).

Lack of use of the cost method of determining the cost of creating or modernizing tourist cluster facilities in the formation of programs of budgetary expenditure on relevant projects. In contrast to the practice of some foreign countries, in Ukraine certain financial resources are first allocated for the years of life cycle of the cluster project, selected within 


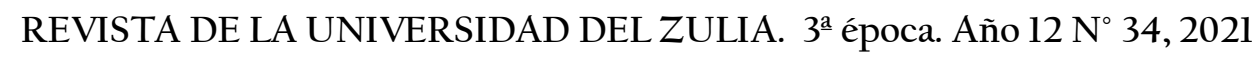

Nina Rybalchenko et al. /// Clasterization tendences of Ukraine's tourism sphere ... 60-75

DOI: http://dx.doi.org/10.46925//rdluz.34.05

the framework of strategic development programs at the state or regional level, and the main task of participants is related to the maximum development of these funds in the declared period. An alternative approach to financing the creation of a tourist cluster should be considered the experience of a number of countries, when the allocation of budgetary funds takes place either after the completion of the entire set of tourist infrastructure of the cluster, or at the final stage of construction (Rybalchenko, 2020; Perminova, 1999).

4. As shows not only the Ukrainian, but also foreign practice, at the beginning of the use of mechanisms of the cluster approach in tourism most often created the so-called tourist and recreational clusters, the mission and purpose of which is associated with the provision of recreation and leisure tourists on the basis of entertainment industry infrastructure and a number of types of tourism (environmental, sports, cultural and informative). However, over time, the situation is changing and tourism and recreation clusters are being replaced by more differentiated and complex projects.

Tourist clusters can be distributed according to certain functional areas of tourist activity (Table 1).

In modern conditions and in the future we should talk primarily about the need for the formation of large sanatorium-resort complexes using the principles of clustering, than about clusters in the field of medical and health tourism. The main difference, based on the classical definitions of cluster in the field of tourism and recreation, will be in the issues of delimitation of areas of responsibility and status of the structure participants. In the context of the health resort complex we are talking about one organization, which provides a wide range of services of therapeutic and recreational orientation. A health cluster, on the other hand, involves a number of independent participants who combine their efforts to achieve the socio-economic objectives of the implemented project (Radchenko, 2019; Pokolodna, Polchaninova, 2019)

From the point of view of further and prospective development of tourism sphere, there is a need for formation and prolongation of the integrative form of cluster structure - a cluster in the sphere of medical and therapeutic and medical tourism, which would unite the advantages of each of the components and would be aimed at solving the problems of the tourist market both at international and national levels. 


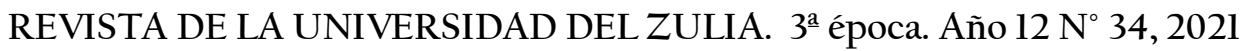

Nina Rybalchenko et al. /// Clasterization tendences of Ukraine's tourism sphere ... 60-75

Table 1.Tourism cluster types

\begin{tabular}{|c|c|c|c|}
\hline № & $\begin{array}{c}\text { The cluster name depending } \\
\text { on the scientific division of } \\
\text { tourism types }\end{array}$ & $\begin{array}{c}\text { The cluster name } \\
\text { depending on the tourism } \\
\text { type defined in the Law of } \\
\text { Ukraine "On Tourism" and } \\
\text { the Strategy for } \\
\text { Sustainable Development } \\
\text { of Tourism and Resorts }\end{array}$ & $\begin{array}{c}\text { Distribution of } \\
\text { tourist clusters by } \\
\text { tourism type }\end{array}$ \\
\hline 1 & $\begin{array}{c}\text { Ecological and sports (Ski) } \\
\text { tourism clusters }\end{array}$ & $\begin{array}{c}\text { Ecological (green) tourism } \\
\text { cluster }\end{array}$ & $33 \%$ \\
\hline 2 & $\begin{array}{c}\text { Cultural and educational, } \\
\text { historical and ethnographic, } \\
\text { and pilgrimage tourism } \\
\text { clusters }\end{array}$ & $\begin{array}{c}\text { Ethnic, rural, cultural, } \\
\text { educational and religious } \\
\text { tourism cluster }\end{array}$ & $25 \%$ \\
\hline 3 & $\begin{array}{c}\text { Tourist and recreational } \\
\text { direction tourist clusters }\end{array}$ & $\begin{array}{c}\text { Mountain and sports } \\
\text { tourism clusters }\end{array}$ & $16,7 \%$ \\
\hline 4 & Cruise tourism clusters & $\begin{array}{c}\text { Scientific and educational, } \\
\text { gastronomic, cruise and } \\
\text { entertainment tourism } \\
\text { clusters }\end{array}$ & $12,5 \%$ \\
\hline 5 & $\begin{array}{c}\text { Medical and health direction } \\
\text { tourism clusters }\end{array}$ & $\begin{array}{c}\text { Medical and health- } \\
\text { improving tourism } \\
\text { clusters }\end{array}$ & $12,5 \%$ \\
\hline
\end{tabular}

Source: compiled on the basis of (Radchenko, 2019).

As you know, the most common are structural and functional schemes of already existing cluster initiatives in different regions of Ukraine, which are located in the West, South and East. In this context, a significant number of initiatives implemented within the framework of rural, green, ethnographic and other types of tourism was stated. However, in modern conditions, the relevance of studying the type of medical and therapeutic tourism clusters. Existing clusters and cluster initiatives allow to assert that their typification should be carried out on the basis of the criterion of reasonable and weighted specialization, so to say "topical". This model of tourist cluster in the medical and therapeutic-health sphere is based on the structure of participants, specific types of their cooperation, determined at the level of reasonable specialization. 


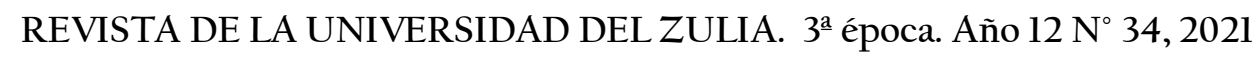

Nina Rybalchenko et al. /// Clasterization tendences of Ukraine's tourism sphere ... 60-75

DOI: http://dx.doi.org/10.46925//rdluz.34.05

According to our belief, one of the promising tourist clusters in the medical and health-improving sphere can be recognized as a cluster in the Kherson region, can provide tourism services balneological direction. This region has a significant amount of natural and recreational resources (mud, geysers, mineral waters, etc.), which will allow this cluster to develop actively. Kherson is a center of health tourism. Tourist cluster will be realized on its territory within 5-6 years. Preliminarily the implementation of the project requires funds from the state and / or local budgets. According to the preliminary estimations, creation of the tourist infrastructure for the new tourist cluster will cost more than $2 \mathrm{mln}$. It is estimated that the creation of a new tourism cluster will cost more than 2 million USD, and the planned extra-budgetary investment must be more than 4,800,000 USD. Dollars. USD (Rybalchenko, 2020), (Pokolodna, Polchaninova, 2012). As part of the creation of this sub-cluster, it is necessary to modernize electrical networks, water supply, as well as to reconstruct driveways and roads in sanatorium-resort complexes.

Prospective is the creation of clusters of medical and health tourism in the ski areas of the Carpathians, in particular in the settlements of Kvasy, Rakhiv and others. On their territory there is a significant number of medicinal mineral springs, a lot of medicinal plants grows, which is facilitated by the special climatic zone, etc. On the creation of clusters of medical and therapeutic and health tourism in Agrotouristic area, it is possible to realize it as part of the promotion of rural health tourism in the settlements of Odessa, Ivano-Frankivsk, Khmelnytsky, Vinnytsia, etc. (in particular, in the cities of Kvasy, Rakhiv, etc.). (In particular, in settlements Bakota, Satanov, Khmelnik, etc.) (Grimak, 2019). So, we should rather talk about the formation of large sanatorium-resort complexes using the principles of clustering, and then about clusters in the field of medical and therapeutic and health tourism. The disadvantages in the organizational and functional activity of clusters of this type include the following:

1) the complexity of differentiation of participants, including the functions that they perform, conventionally among them can be distinguished leading and auxiliary participants, as well as other partners;

2) imperfect state of the resource and infrastructure base of medical and health tourism clusters (it is clear that they should include, first of all, not tourist attractions, but have the necessary resource and material base of medical and health tourism); 


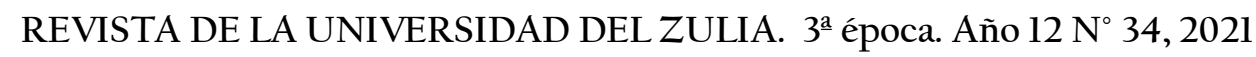

Nina Rybalchenko et al. /// Clasterization tendences of Ukraine's tourism sphere ... 60-75

DOI: http://dx.doi.org/10.46925//rdluz.34.05

3) lack of determination of the key vectors of the participants of medical and health tourism clusters, and, consequently, their interaction directions [ibid].

Multilevel model of tourist cluster, in particular in medical and therapeutic and health-improving spheres, can also be considered from the position of its basic essence components, schematically represented by corresponding colocenters (Fig. 2). In this case, the basic level of tourist cluster, which functions in medical and therapeutic and healthimproving spheres, is appropriate to present in the mnemonic (schematic) model as a central circle (core). The constituent parts of this colocenter are the entities that provide basic services to the recreationists, as well as for the maintenance of medical and tourist attractions.

There is no doubt that the tourism industry has been shaken by the pandemic "COVID-19," resulting in a serious crisis in this area and reset serious imbalances, resulting in the results of the fall and the global economy. The "COVID-19" pandemic acted as a catalyst of crisis processes which occurred in the form of financial shocks, - notes G. Scherbakov in his article "Influence and consequences of the COVID-19 pandemic: social and economic dimensions.

The efficiency and innovation in the tourism sphere can be provided by tourist clusters, because the creation of 10 such clusters within 5 years gives the possibility for the state to get additional 500 million dollars into the budget, to attract from 800 million to 150 million dollars of investments into the tourist sphere, and also to create 800 workplaces in it and in the adjacent spheres (Georgieva, \& Malpass,2020; Grimak, 2019).

The next linking colocenters are represented by partner structures. They provide additional services to the recreationists on the territory of the tourist cluster. At this level, it is important to establish cooperation with the basic subjects of the tourist cluster (i.e. internal first colocenter). As for ensuring the affiliation of the tourist cluster functioning through the organization of accompanying activities, it is represented graphically by the appropriate so to say peripheral colocenter, within which the state authorities, selfgoverning organizations, etc. carry out their activities. It should be emphasized that at the level of tourist cluster support it can monitor the state of establishing ties between "partners" and "main subjects of tourist cluster", providing respectively basic and additional tourist services. 


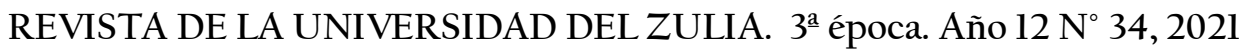

Nina Rybalchenko et al. // Clasterization tendences of Ukraine's tourism sphere ... 60-75

DOI: http://dx.doi.org/10.46925//rdluz.34.05

Fig. 2. The place of the tourism cluster of medical and therapeutic and recreational direction in the system of public policy. Source: compiled on the basis of the provisions of the Law of Ukraine "About tourism " (zakon0.rada.gov.ua, 2015) and analysis of existing scientific developments in this area (www.ukrinform.ua, 2018).

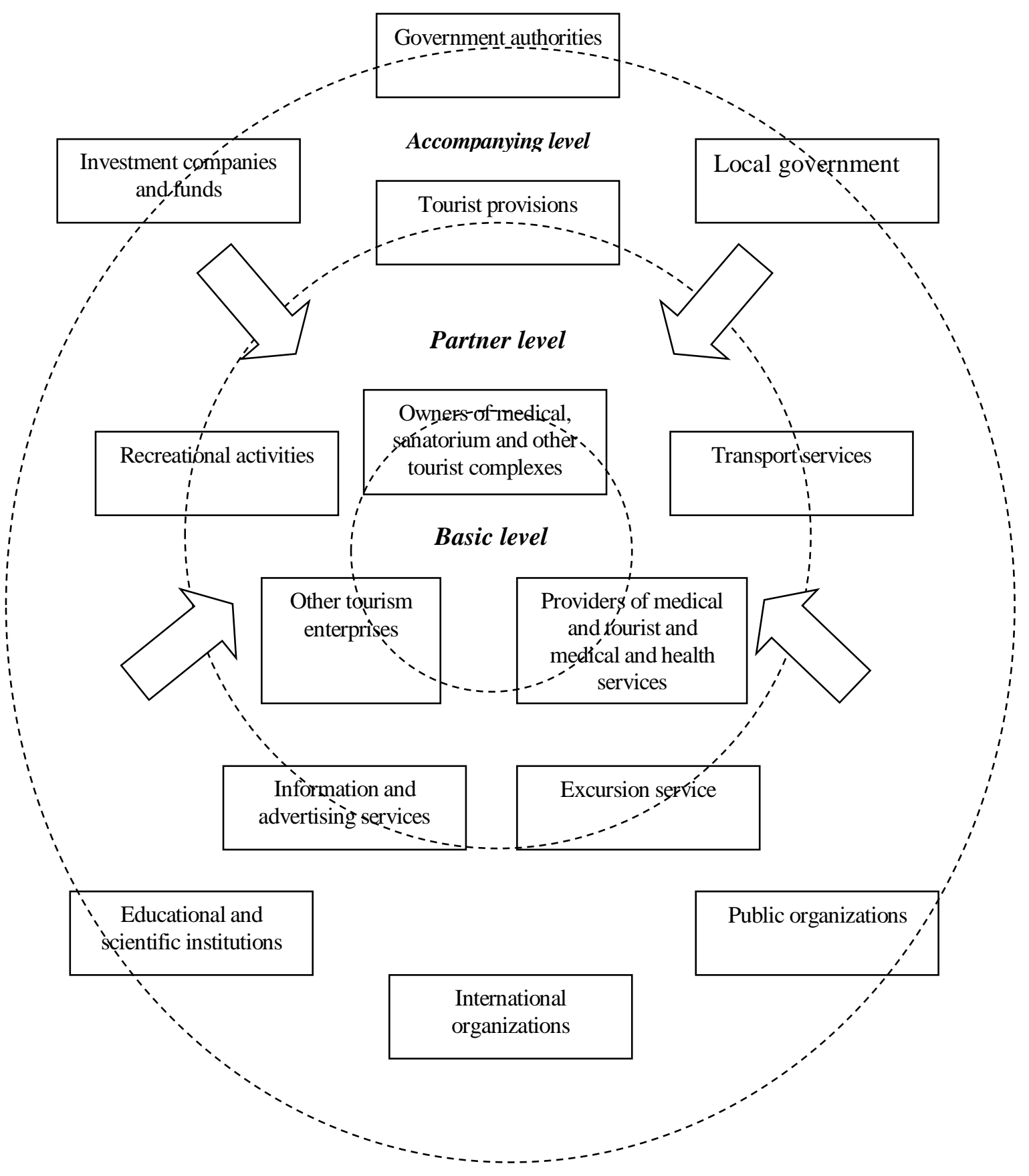

Conclusions

Thus, in the process of the study it was found out that overcoming the problems of pandemic coronavirus COVID-19 "came to the forefront, which combined economic, social, 
REVISTA DE LA UNIVERSIDAD DEL ZULIA. 3é época. Año $12 \mathrm{~N}^{\circ}$ 34, 2021

Nina Rybalchenko et al. /// Clasterization tendences of Ukraine's tourism sphere ... 60-75

DOI: http://dx.doi.org/10.46925//rdluz.34.05

demographic, environmental consequences, as well as the distribution of tourist clusters in Ukraine, which is modified by increasing the influence of exogenous and endogenous factors on the sphere of tourism. Provided such influence remains in the nearest future, tourist clusters will actively develop in the sphere of cultural-cognitive, ecological, rural, sports, medical, therapeutic and e-tourism. COVID-19 pandemic acted as a catalyst for crisis processes that occurred in the form of financial turmoil.

Conditions for clustering should be shaped in such a way as to strive to attract investment, especially foreign investment, but for this participants often lack the necessary managerial knowledge and they are forced to seek support from the authorities or business partners.

In order to help these initiators of tourism development, as well as other entrepreneurs in the tourism sector throughout Ukraine, we propose to coordinate the actions of the authorities, professional tourist associations and entities to organize tourism on the terms of mutual support, assistance (especially advisory and institutional) and both tangible and intangible benefits.

\section{References}

Bourne, R. A. (2021). Economics in One Virus: An Introduction to Economic Reasoning through COVID19. Cato Institute.

Caro, D. H. (2021). Transforming Nations after the COVID-19 Pandemic: A Humanitarian and Planetary Systems Perspective. Springer Nature. https://doi.org/10.1007/978-3-030-61810-0

Creation of the network "Tourist clusters 300+". URL: https://www.ukrinform.ua/rubricpresshall/2509656-stvorenna-merezi-turisticni-klasteri-300.html.

Galloway S. Post Corona: From Crisis to Opportunity. NY.: Portfolio, 2020. 256 p.

Galloway, T., Bowra, A., Butsang, T., \& Mashford-Pringle, A. (2020). Education in uncertainty: Academic life as Indigenous health scholars during COVID-19. International Review of Education, 1-16.

Gans, J. (2020). Economics in the Age of COVID-19. MIT Press.

Georgieva, K., \& Malpass, D. (2020). Joint Press Conference on COVID-19 by IMF Managing Director and World Bank Group President. URL: https:// www.imf.org/external/pubs/ft/fandd/2020/06/ turning-crisis-into-opportunity-kristalinageorgieva. htm (дата обращения: 22.05.2021) 
REVISTA DE LA UNIVERSIDAD DEL ZULIA. 3é época. Año $12 \mathrm{~N}^{\circ} 34,2021$

Nina Rybalchenko et al. /// Clasterization tendences of Ukraine's tourism sphere ... 60-75

DOI: http://dx.doi.org/10.46925//rdluz.34.05

Grimak, O. Ya. (2019). Socio-economic aspects of the state policy of integrated development of the tourism industry in Ukraine. Public administration and customs administration. № 1 (18). Pp. 98-103.

Hernández Barrios, Y., Fonte Galindo, L., Zabala Argüelles, M., \&e Pérez Chacón, D. (2021). Mejorando la respuesta a la COVID-19: reorientación de los esfuerzos de comunicación de riesgos hacia cuestiones de equidad. Revista Latinoamericana De Difusión Científica, 3(5), 3-8. https://doi.org/10.38186/difcie.35.01

Khlopyak, S. V. (2015). State regulation of tourism in Ukraine (Doctoral dissertation, degree of Candidate of Economic Sciences, special: 08.00. 03 - "Economics and management of the national economy / Serhiy Khlopyak).

Kovaleva, Yu. M., \& Alisheva, NV. (2008). Practical examples of the functioning of clusters in the world. The mechanism of economic regulation. 2008. № 3 (2), Vol.1. Pp. 92-100.

Lytvynenko, N., Khmara, M., Rylach, N., Spektor, O., \& Orekhov, S. (2020). Methods of calculating the efficiency of clusters and possible modalities for their development, Revista De La Universidad Del Zulia, 11(31), 97-118. https://doi.org/10.46925//rdluz.31.08

Nikitenko, V. A., Voronkova, V. H., Andriukaitiene, R., \& Oleksenko, R. I. (2021). The crisis of the metaphysical foundations of human existence as a global problem of postmodernityand the ways of managerial solutions. Propósitos y Representaciones, 9 (SPEl), 928.

Official website of the Verkhovna Rada of Ukraine. URL: https://www.rada.gov.ua/.

On licensing of economic activities: Law of Ukraine (2015) of March 2, № 222-VIII (as amended). URL: http://zakon0.rada.gov.ua/laws/show/222-19/page.

Ortina, G.V. (2015). Influence of globalization tendencies on the conditions of providing anticrisis strategy in the process of realization of the state economic policy. http://www.economy.nayka.com.ua/?op=1\&z=4179.

Perminova G. (1999). Trends in tourism development in Ukraine at the turn of the millennium in the context of world experience. Ukraine, Ukrainians, Ukrainian studies in the twentieth century. in sources and documents: coll. Science. pr .: in 2 h. K., 1999. Ch. 2. S. $570-577$.

Pokolodna M.M., Polchaninova I.L. (2012). Recreational complexes of the world (including tourist resources of Ukraine). URL: https://tourlib.net/books ukr/pokolodna.htm.

Porter, M. (1993). International competition: Per. with English / Ed. and with a preface by V.D. Shchetinin. M.: International Relations, 896, 3.

Pylypenko S. (2002). Tourism industry of Ukraine: investment aspect. Commander. Visn. state employee. № 1. S. 38-40

Radchenko, O.O. (2019). The role and tasks of the state in the field of development of the tourist industry of Ukraine. Public Administration Studies, 1 (11), 80-80. URL: 
REVISTA DE LA UNIVERSIDAD DEL ZULIA. 3é época. Año $12 \mathrm{~N}^{\circ}$ 34, 2021

Nina Rybalchenko et al. /// Clasterization tendences of Ukraine's tourism sphere ... 60-75

DOI: http://dx.doi.org/10.46925//rdluz.34.05

http://studio.ipk.edu.ua/wp-content/uploads/2020/07/Radchenko-DUS-11.pdf.

Rape, R.V. (2011). Features of development of cluster formations in the tourism industry of Ukraine and Poland.

Rybalchenko N. P. (2020). Sutnist' vykorystannya informatsiynykh tekhnolohiy u sferi turyzmu. Turystychnyy ta hotel'no-restorannyy biznes v Ukrayini: problemy rozvytku ta rehulyuvannya: materialy KHI Mizhnarodnoyi naukovo-praktychnoyi konferentsiyi (19-20 bereznya 2020 r., m. Cherkasy). u 2-kh tomakh. T. 1. Cherkasy: CHDTU. S. 118-120.

Rybalchenko N.P. (2018). The main ways to stimulate the tourist attractiveness of Ukraine. Formation of educational space in the information society: materials of the International scientific-practical Internet conference (April 26-27, 2018, Zaporozhye), Zaporozhye: ZDIA. Pp. 101-102.

Rybalchenko, N.P. (2018). Problems of state regulation in reforming the tourism industry of Ukraine. Scientific Journal Virtus, (25), 208-211.

Schwab, K., \& Malleret, T. (2020). COVID-19: The Great Reset. Forum Publishing.URL: http://reparti.free.fr/ schwab2020.pdf (дата обращения: 22.05.2021)

Shcherbakov G.A. (2021). Impact and Consequences of the COVID-19 Pandemic: SocioEconomic Dimension. WORLD (Modernization. Innovation. Development). 2021; 12 (1): 8 22. https://doi.org/10.18184/2079-4665.2021.12.1.8-22

Shelemet'eva T. V. (2019). The current system of tourism development management in Ukraine. Intellect XXI. No. 1.P. 121-126.

Strategy for the development of tourism and resorts: order of the Cabinet of Ministers of Ukraine (2008) dated August 6, № 1088-r. URL: http://www.kmu.org.ua.

Stratehiya rozvytku turyzmu i kurortiv : rozporyadzhennya Kabinetu Ministriv Ukrayiny vid 6 serpnya 2008 r. № 1088-r.URL: http://www.kmu.org.ua.

Timchishin-Chemeris, Yu. V. (2015). Tourist cluster is a form of development and success of tourist activity in the region. http:/ucluster.org/sokolenko/2009/09/stvorennyamizhnarodnyx-klasteriv-u-galuzi-zelenogo-turizmu-chastina-persha/.

Voronkova, V. H., Nikitenko, V. A., Teslenko, T. V., \& Bilohur, V. E. (2020). Impact of the worldwide trends on the development of the digital economy. Amazonia investiga, 9 (32), 8190. https:/www.amazoniainvestiga.info/index.php/amazonia/issue/archive 